PERINATALNE KOMPLIKACIJE TRUDNOĆA KOMPLIKOVANIH MIOMIMA UTERUSA

\title{
PERINATAL COMPLICATIONS OF PREGNANCIES COMPLICATED BY UTERINE FIBROIDS
}

\author{
Radmila Sparić ${ }^{1,2}$, Đina Tomašević ${ }^{1}$ \\ ${ }^{1}$ Medicinski fakultet, Univerzitet u Beogradu, Beograd, Srbija \\ ${ }^{2}$ Klinika za ginekologiju i akušerstvo, Univerzitetski klinički centar \\ Srbije, Beograd, Srbija. \\ ' Faculty of Medicine, University of Belgrade, Belgrade, Serbia \\ ${ }^{2}$ Clinic for Gynecology and Obstetrics, University Clinical Centre of \\ Serbia, Belgrade, Serbia
}

\section{SAŽETAK}

Miomi su najčešći tumori ženskih reproduktivnih organa koji se sastoje od glatkih mišićnih ćelija, fibroblasta i ekstracelularnog matriksa. Razvijaju se od menarhe do menopauze. Dijagnostikuju se kod $10-20 \%$ žena u toku reproduktivnog perioda. Njihova veličina varira od jedva vidljivih nodusa do velikih tumora.

Promena veličine mioma tokom trudnoće i nakon porođaja je predmet brojnih istraživanja. Većina studija ukazuje na postojanje značajnog porasta veličine mioma u prvom trimestru, nepromenjenu veličina tokom drugog i trećeg trimestra i smanjenje veličine nakon porođaja.

Uticaj mioma na trudnoću zavisi od njihovog broja, lokalizacije i veličine. Miomi se povezuju sa nastankom brojnih perinatalnih komplikacija: krvarenjem u trudnoći, spontanim pobačajima, bolom usled crvene degeneracije, prevremenim porođajem, abrupcijom posteljice, placentom previjom, intrauterinim zastojem u rastu ploda, fetalnom malprezentacijom, zastojem porođaja, povećanom učestalošću carskih rezova, atonijom materice i postpartalnim krvarenjem.

Terapija mioma u trudnoći podrazumeva mirovanje i praćenje uz simptomatsku terapiju u slučaju pojave bolova, kao i intenzivan nadzor stanja fetusa. Veoma retko, neophodna je miomektomija u trudnoći.

Miomektomija tokom carskog reza se godinama smatrala kontraindikovanom. Novija istraživanja pokazuju da ova procedura ne mora biti povezana sa povećanim rizikom perioperativnih komplikacija. Njene prednosti su dve operacije u okviru jedne pri čemu se izbegavaju rizici ponovne laparotomije i anestezije. Najčešće postpartalne komplikacije mioma su krvarenje i infekcija.

Ključne reči: miomi, trudnoća, perinatalne komplikacije, miomektomija.

\begin{abstract}
Fibroids (myomas) are the most common tumors of the female reproductive organs, consisting of smooth muscle cells, fibroblasts and extracellular matrix. They develop from menarche to menopause. They are diagnosed in $10-20 \%$ women of reproductive age. Their size varies from barely visible nodules to large tumors. Change in the size of fibroids during pregnancy and after childbirth is the subject of numerous studies. Most studies indicate a significant increase in the size of fibroids during the first trimester, unchanged size during the second and the third trimester and a decrease in their size after the delivery.

The effect of fibroids on pregnancy depends on their number, location and size. Myomas are associated with numerous perinatal complications: bleeding in pregnancy, miscarriages, pain due to red degeneration, preterm birth, placental abruption, placenta previa, intrauterine growth restriction, fetal malpresentation, prolonged labor, increased cesarean section rate, uterine atony and postpartum hemorrhage.

Treatment of fibroids in pregnancy includes bed rest and follow-up with symptomatic therapy in case of pain, as well as intensive monitoring of the fetus. Very rarely, myomectomy may be necessary during pregnancy.

Myomectomy during caesarean section has been considered contraindicated for years. Recent research demonstrates that this procedure may not be associated with an increased risk of perioperative complications. Its advantages include performing two operations within one surgical procedure, while avoiding the risks of repeated laparotomy and anesthesia.
\end{abstract}

The most common postpartum complications of fibroids are bleeding and infection.

Keywords: fibroids, pregnancy, perinatal complications, myomectomy. 


\section{UVOD}

Miomi (fibromi ili leiomiomi) predstavljaju najčešće tumore ženskih reproduktivnih organa $[1,2]$. Sastoje se od glatkih mišićnih ćelija, fibroblasta i ekstracelularnog matriksa [3]. Obilna količina ekstracelularnog matriksa, koju grade glikozaminoglikani i gusto zbijeni intersticijumski kolagen, čini tkivo mioma dva do četiri puta čvršćim od miometrijuma [4]. Ovi tumori su jasno ograničeni od okolnog tkiva pseudokapsulom, koja nastaje kao rezultat kompresije miometrijuma njihovim progresivnim rastom. Pseudokapsula predstavlja neurofibrovaskularnu strukturu, koja okružuje miom i koja sadrži brojne neuropeptide i neurotransmitere, značajne za reproduktivnu i seksualnu funkciju [3].

Miomi se razvijaju od menarhe do menopauze i utiču na reproduktivno zdravlje tokom većeg dela života žene. Njihovo praćenje i lečenje uzrokuje značajne materijalne troškove, koje dodatno povećavaju miomima uzrokovane perinatalne komplikacije [5].

\section{EPIDEMIOLOGIJA I ETIOPATOGENEZA MIOMA}

Miomi se dijagnostikuju kod 10 - 20\% žena u toku reproduktivnog perioda [6]. Učestalost mioma u trudnoći se kreće od 2,7\% u opštoj populaciji, preko 12,6\% u populaciji podvrgnutoj postupcima asistirane reprodukcije, do $25 \%$ u populaciji žena starije životne dobi koje se podvrgavaju postupku fertilizacije in vitro sa jajnim ćelijama davaoca [7].

Epidemiološki faktori rizika za nastanak i razvoj mioma uključuju: godine starosti, rasu, indeks telesne mase, nasleđe, polne hormone, životne navike (konzumiranje alkohola i kofeina, ishrana bogata crvenim mesom i sojom, pušenje, fizička aktivnost, stres), uticaj životne sredine, kao i uticaj hroničnih bolesti, poput hipertenzije [1].

Uprkos činjenici da su miomi veoma česti tumori, njihova etiopatogeneza je nedovoljno proučena [8]. Transformacija miometrijalne stem ćelije materice $u$ ćeliju mioma sposobnu za klonalnu ekspanziju predstavlja inicijalni korak u formiranju mioma. Drugi korak u nastanku tumora je produkcija i akumulacija ekstracelularnog matriksa [9].

Sam rast mioma zavisi od steroidnih hormona. Progesteron je dominantan faktor u stimulaciji njihovog rasta. Njegov uticaj na razvoj ovih tumora ogleda se u efektima na ekspresiju gena povezanih sa citokinima i povećanju koncentracije pojedinih faktora rasta [8].

\section{BIOLOŠKO PONAŠANJE MIOMA TOKOM TRUDNOĆE}

Miomi su jasno ograničeni, okruglasti, tvrdi, sivobeličasti tumori, čija veličina varira od makroskopski jedva

\section{INTRODUCTION}

Myomas (fibromas or leiomyomas) are the most common tumors of the female reproductive organs $[1,2]$. They consist of smooth muscle cells, fibroblasts and extracellular matrix [3]. A profuse amount of extracellular matrix, which is made up of glycosaminoglycans and densely packed interstitial collagen, makes the myoma tissue two to four times firmer than the myometrium [4]. These tumors are clearly delineated by a pseudocapsule which separates them from the surrounding tissue. The pseudocapsule is formed as the result of the compression of the myometrium by the constant growth of the tumors. The pseudocapsule is a neurofibrovascular structure surrounding the myoma, which contains numerous neuropeptides and neurotransmitters, significant for reproductive and sexual function [3].

Fibroids develop from menarche to menopause and affect the reproductive health of a woman throughout a larger part of her life. The follow-up and treatment of these tumors generates significant financial cost, which is additionally increased by perinatal complications caused by myomas [5].

\section{EPIDEMIOLOGY AND ETIOPATHOGENESIS OF MYOMAS}

Myomas are diagnosed in $10-20 \%$ of women during the reproductive period [6]. The frequency of myomas in pregnancy ranges from $2.7 \%$ in the general female population, to $12.6 \%$ in the female population undergoing assisted reproductive procedures, to $25 \%$ in the population of older women undergoing in vitro fertilization with donor egg cells [7].

Epidemiological risk factors for the formation and development of fibroids include: age, race, body mass index, hereditary factors, sex hormones, lifestyle (alcohol and caffeine consumption, diet rich in red meat and soy, smoking, physical activity, stress), environmental factors, effects of chronic disease, such as hypertension [1].

Despite the fact that myomas are very frequent tumors, their etiopathogenesis has still not been sufficiently elucidated [8]. The transformation of a myometrial uterine stem cell into a myoma cell capable of clonal expansion is the initial step in the formation of a myoma. The second step in tumor development is the production and accumulation of extracellular matrix [9].

The growth of myomas themselves depends on steroid hormones. Progesterone is a dominant factor in the stimulation of their growth. Its influence on tumor development is reflected in the effects on the expression of genes linked to cytokines and the increase in the concentration of certain growth factors [8]. 
vidljivih nodusa do masivnih tumora, koji mogu ispuniti malu karlicu [9]. Promena veličine mioma tokom trudnoće i nakon porođaja je predmet brojnih istraživanja $[7,10,11]$. Li i saradnici [11] navode da $60-78 \%$ mioma ne pokazuje značajne promene zapremine tokom trudnoće, a slažu se da se veličina mioma smanjuje nakon porođaja, kao posledica remodeliranja uvećane materice tokom puerperijuma.

Rosati i saradnici [10] su pokazali da se zapremina mioma uvećava tokom prvog trimestra trudnoće, ostaje nepromenjena tokom drugog i trećeg, a smanjuje se tokom puerperijuma.

Vitagliano i saradnici [12] su obavili analizu ukupno 12 studija koje su istraživale uticaj trudnoće na veličinu mioma. Trend porasta veličine mioma tokom prvog trimestra je pokazan u svim ispitivanim studijama, dok su podaci o promenama veličine mioma u literaturi tokom drugog i trećeg trimestra neusaglašeni.

U studiji koju su objavili Loflin i saradnici [13], pokazano je značajno smanjenje veličine submukoznih mioma u odnosu na intramuralne, subserozne i miome na peteljci, kao i smanjenje veličine mioma nakon porođaja u odnosu na prvi trimestar trudnoće.

Deli Karpini i saradnici [14] su u svom istraživanju uočili značajan porast veličine mioma u ranoj trudnoći u odnosu na veličinu pre trudnoće, nepromenjenu veličinu mioma tokom druge polovine trudnoće i značajno smanjenje veličine mioma nakon porođaja.

\section{MEHANIZMI NASTANKA PERINATALNIH KOMPLIKACIJA}

Oko 10 - 40\% žena sa miomima materice imaju miomima uzrokovane komplikacije tokom trudnoće $[11,15]$. Uticaj mioma na trudnoću umnogome zavisi od njihovog broja, lokalizacije i veličine. Miomi utiču na rastezanje materice; dovode do promena u strukturi endometrijuma i obliku materične šupljine; utiču na efikasnost kontrakcija materice tokom porođaja i u puerperijumu; a mogu predstavljati i prepreku normalnom toku porođaja (tzv. miomi previja) $[6,16]$. Submukozni miomi sa sekundarnim degenerativnim promenama mogu predstavljati žarište infekcije i/ili hronične inflamacije. Citokini koji se stvaraju u ovim miomima doprinose povećanom riziku od prevremenog porođaja. Distorzija šupljine materice može imati kompresivni efekat i dovesti do poremećaja uteroplacentne cirkulacije. Aktivnost enzima oksitocinaze kod žena sa miomima je smanjena, što uzrokuje povišene vrednosti oksitocina, što potom doprinosi nastanku prevremenih porođaja [15]. Takođe, miomi mogu ograničiti pokrete ploda tokom trudnoće [6].

\section{BIOLOGICAL BEHAVIOR OF MYOMAS DURING PREGNANCY}

Myomas are well defined, round, hard, grey-white tumors, whose size varies from macroscopically barely visible nodes to massive tumors, which may occupy the entire lesser pelvis [9]. Myoma size during pregnancy and after delivery has been the subject of numerous studies $[7,10,11]$. Lee et al. [11] state that $60-78 \%$ of myomas do not show significant changes in volume during pregnancy and they agree that the size of myomas decreases after delivery, as the result of the remodeling of the enlarged uterus during the puerperium.

Rosati et al. [10] have shown that myoma volume increases during the first trimester of pregnancy, remains the same during the second and the third trimester, and decreases during the puerperium.

Vitagliano et al. [12] have performed an analysis of a total of 12 studies examining the impact of pregnancy on myoma size. The trend of myoma size increase during the first trimester of pregnancy has been reported in all of the analyzed studies, while the data on the changes in myoma size during the second and the third trimester is not consistent.

A study published by Laughlin et al. [13] has reported a significant decrease in the size of submucosal myomas in comparison to intramural, subserosal, and pedunculated myomas, as well as a decrease in the size of myomas after delivery, as compared to the first trimester of pregnancy.

In their study, Delli Carpini et al. [14] observed a significant increase in myoma size in early pregnancy, as compared to the size prior to pregnancy, unchanged myoma size during the second half of the pregnancy, and a significant decrease in myoma size after delivery.

\section{MECHANISMS OF THE DEVELOPMENT OF PERINATAL COMPLICATIONS}

Around $10-40 \%$ of women with uterine fibroids have myoma-induced complications during pregnancy $[11,15]$. The effect of myomas on pregnancy largely depends on their number, localization, and size. Fibroids affect uterine distension; they lead to changes in the structure of the endometrium and in the shape of the uterine cavity; they affect the efficiency of uterine contractions during delivery and the puerperium; and can also impede the normal course of delivery (so called myoma previa) $[6,16]$. Submucosal myomas with secondary degenerative changes may be a focus of infection and/or chronic inflammation. Cytokines produced in these myomas contribute to increased risk of premature delivery. The distortion of the uterine cavity may have a compression effect and lead to disruption in the utero- 


\section{KOMPLIKACIJE MIOMA TOKOM TRUDNOĆE I POROĐAJA}

Miomi u trudnoći se povezuju sa nastankom brojnih perinatalnih komplikacija, kao što su: krvarenje u trudnoći, spontani pobačaji, bol usled crvene degeneracije, intrauterini zastoj u rastu ploda, karlična prezentacija, kosi i poprečni položaj ploda, prevremeni porođaj, prevremena preterminska ruptura plodovih ovojaka, abrupcija placente, placenta previja, zastoj porođaja, povećana učestalost carskih rezova i operativnih vaginalnih porođaja, atonija materice, postpartalna hemoragija i ruptura materice $[6,11,16,17]$.

Rizik nastanka krvarenja u ranoj trudnoći određen je lokalizacijom mioma i značajno je povećan u slučaju insercije posteljice u blizini mioma [11].

Učestalost spontanih pobačaja je povećana dva do tri puta kod trudnica sa miomima. Rani spontani pobačaji su češći kod žena sa miomima tela materice i u slučajevima implantacije na mestu submukoznih mioma. Smatra se da miomi dovode do pobačaja svojim kompresivnim efektom, povećanjem kontraktilnosti materice i kompromitovanjem snabdevanja krvlju posteljice i ploda $[11,18]$.

Veliki i multipli miomi povećavaju rizik za nastanak prevremenog porođaja, jer su manje rastegljivi od zdravog miometrijuma, što dovodi do prevremenih kontrakcija materice i dilatacije grlića [18].

Podaci o preterminskoj rupturi plodovih ovojaka kod trudnica sa miomima su neusaglašeni: od toga da je rizik smanjen, preko neizmenjenog rizika do povećanog rizika u odnosu na opštu populaciju. Autori koji su istraživali ovaj problem navode učestalost od 7\% [19].

Najčešća komplikacija mioma u trudnoći je pojava lokalizovanog bola u abdomenu, kao posledica crvene degeneracije mioma. Klinički se opisuje kao bol u predelu mioma ili opšta bolna osetljivost posle palpacije, sa povišenom telesnom temperaturom, leukocitozom, mukom i povraćanjem. Smatra se da brzi rast mioma tokom trudnoće rezultira nedovoljnom snabdevenošću tkiva krvlju, sa posledičnom tkivnom anoksijom i pojavom bola. Drugi uzrok bola mogu biti promene arhitektonike krvnih sudova, uzrokovane uvećanjem gravidne materice, što takođe dovodi do tkivne anoksije i nekroze. Treći mogući uzrok može biti lokalno oslobađanje prostaglandina iz nekrotičnih ćelija mioma $[6,11]$.

Smatra se da je pojava intrauterinog zastoja u rastu ploda češća u trudnoćama u kojima je insercija placente na mestu postojanja mioma materice, što može uzrokovati poremećaj perfuzije placente [20].

Malprezentacija ploda sreće se u 13\% trudnoća komplikovanih miomima. Češće se javlja u slučaju velikih, submukoznih, multiplih i mioma lokalizovanih u predelu donjeg materičnog segmenta [11]. Najčešća je placental circulation. In women with myomas, the activity of the enzyme oxytocinase is reduced, which causes elevated oxytocin levels, which, in turn, contributes to the occurrence of premature deliveries [15]. Also, myomas may limit fetal movement during pregnancy [6].

\section{MYOMA COMPLICATIONS DURING PREGNANCY AND DELIVERY}

Fibroids in pregnancy are associated with the development of numerous perinatal complications, such as: bleeding in pregnancy, miscarriages, pain due to red degeneration, intrauterine growth restriction, breech presentation of the fetus, transverse and oblique position of the fetus, preterm birth, preterm premature rupture of fetal membranes, placental abruption, placenta previa, prolonged labor, increased cesarean section rate and increased rate of operative vaginal deliveries, uterine atony, postpartum hemorrhage, and rupture of the uterus $[6,11,16,17]$.

Risk of hemorrhage in early pregnancy is determined by myoma localization and is significantly increased in case of placental insertion in the vicinity of the myoma [11].

The frequency of miscarriages is two to three times higher in women who have fibroids. Early miscarriages are more frequent in women with myomas of the body of the uterus and in cases of implantation at the site of submucosal myomas. It is believed that myomas cause miscarriage with their compression effect, with their influence on the increase in the contractility of the uterus, and by compromising blood supply to the placenta and the fetus $[11,18]$.

Large and multiple myomas increase the risk of premature delivery, as they are less flexible than the healthy endometrium. This leads to premature contractions of the uterus and premature dilatation of the cervix [18].

Data on preterm rupture of the fetal membranes in pregnant women who have myomas are not consistent. They range from data demonstrating that the risk is decreased, to data demonstrating no change in the level of risk, to data showing an increased risk, as compared to the general population. Authors who have researched this issue have reported a 7\% rate of occurrence [19].

The most frequent complication of myomas in pregnancy is localized pain in the abdomen, which is the result of red degeneration of the myomas. Clinical$l y$, it is described as pain in the region of the myomas or general painful sensitivity upon palpation, accompanied by elevated body temperature, leukocytosis, nausea and vomiting. It is believed that the rapid growth of the myomas during pregnancy results in inadequate blood supply to the tissue, resulting in tissue anoxia and pain. Another cause of pain may be found 
karlična prezentacija, mada miomi mogu dovesti i do kosog i poprečnog položaja ploda [18].

Abrupcija posteljice je retka, ali potencijalno fatalna komplikacija trudnoće. Rizik za njen nastanak je trostruko povećan kod žena sa miomima. Faktori rizika su submukozni i retroplacentni miomi, kao i miomi zapremine veće od $200 \mathrm{~cm}^{3}$. Jedan od mogućih mehanizama nastanka abrupcije jeste smanjen protok krvi do mioma i okolnog tkiva miometrijuma, što rezultira delimičnom ishemijom i nekrozom decidue u tkivu posteljice koje prekriva miom [11].

Smatra se da je placenta previja dva puta češća kod žena sa miomima. Kao faktor rizika navode se prečnik mioma veći od $50 \mathrm{~mm}$ i miomi lokalizovani u predelu donjeg materičnog segmenta $[11,18,21]$.

Faktori koji doprinose većoj učestalosti carskih rezova kod trudnica sa miomima su malprezentacija, distocija i opstrukcija porođajnog kanala miomima u predelu donjeg materičnog segmenta. Rizik se povećava proporcionalno veličini i zapremini mioma, a veći je u slučaju mioma donjeg materičnog segmenta $[11,18,19]$. Prospektivna kohortna studija iz Sjedinjenih Američkih Država je pokazala da je povećani rizik porođaja carskim rezom kod žena sa pojedinačnim miomima proporcionalan veličini mioma, a kod žena sa multiplim miomima ukupnoj zapremini mioma [22].

Učestalost postpartalne hemoragije iznosi oko $2,5 \%$. Zbog toga su i postpartalne histerektomije kod ovih žena češće nego u opštoj populaciji (Slika 1) [11]. Multipli miomi, veliki miomi i miomi lokalizovani u predelu donjeg materičnog segmenta povećavaju rizik za nastanak krvarenja [23].

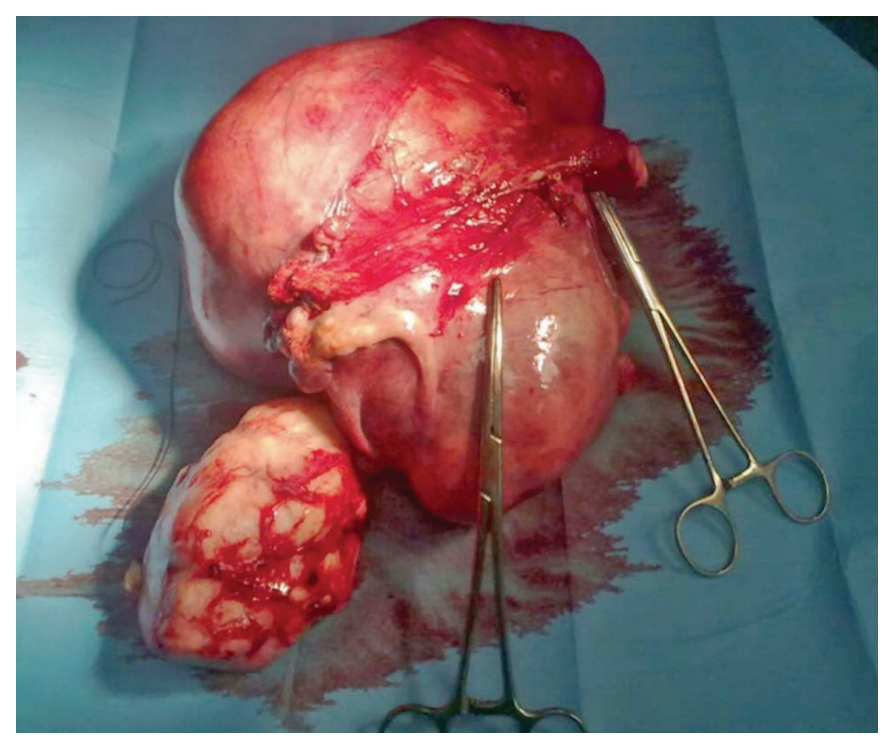

Slika 1. Postpartalna histerektomija: materica deformisana multiplim miomima nakon carskog reza

Figure 1. Postpartum hysterectomy: uterus deformed by multiple fibroids after cesarean section in the changes in the architectonics of blood vessels, resulting from the enlargement of the gravid uterus, which also leads to tissue anoxia and necrosis. A third possible cause of pain may be the localized release of prostaglandin from necrotic myoma cells $[6,11]$.

It is believed that the occurrence of intrauterine fetal growth restriction is more common in pregnancies where the placental insertion is at the site of uterine myoma(s), which may result in the disruption of placental perfusion [20].

Fetal malpresentation is found in $13 \%$ of pregnancies complicated by fibroids. It is more frequent in cases of large, submucosal and multiple myomas, as well as in cases where the myomas are localized in the region of the lower uterine segment [11]. The breech presentation is the most common malpresentation, although myomas may lead also to the oblique and the transverse position of the fetus [18].

Placental abruption is a rare, but potentially fatal complication of pregnancy. The risk of its occurrence is three times greater in women with myomas. The risk factors for its occurrence are submucosal and retroplacental myomas, as well as fibroids that have a volume greater than $200 \mathrm{~cm}^{3}$. One of the possible mechanisms of the occurrence of abruption is decreased blood flow to the myoma and the surrounding myometrial tissue, which results in partial ischemia and necrosis of the decidua in the tissue of the placenta covering the myoma [11].

It is believed that placenta previa is twice more common in women with myomas. A diameter of the myoma greater than $50 \mathrm{~mm}$ and myomas localized in the region of the lower uterine segment are considered as risk factors [11,18,21].

Factors contributing to a higher frequency of cesarean sections in pregnant women with myomas are fetal malpresentation, dystocia and obstruction of the birth canal by myomas in the region of the lower uterine segment. The risk increases proportionately to the size and volume of the myoma, and is greater in cases of myomas in the lower uterine segment $[11,18,19]$. A prospective cohort study from the United States of America showed that the increased risk of cesarean section delivery in women with individual myomas was proportionate to the size of the myoma, and in women with multiple myomas this increased risk was proportionate to the total volume of the myomas [22].

The frequency of the occurrence of postpartum hemorrhage is around $2.5 \%$. This is why postpartum hysterectomy in these women is more common than in the general population (Figure 1) [11]. Multiple myomas, large myomas, and myomas localized in the region of the lower uterine segment increase the risk of hemorrhage [23].

One of the most severe complications during preg- 
Jedna od najtežih komplikacija tokom trudnoće i porođaja je ruptura materice. Ona može dovesti do krvarenja, šoka, histerektomije, pa čak i smrti majke i ploda [24]. Većinom se dešava u trećem trimestru trudnoće ili tokom porođaja, kada je intrauterini pritisak povišen. Ožiljci na materici, od prethodne miomektomije, uzrokuju smanjenje elastičnosti i čvrstine miometrijuma na mestu ožiljka usled zamene mišićnog tkiva fibroznim. Porođaj se u ovakvim slučajevima po pravilu završava carskim rezom $[11,24]$.

\section{UTICAJ MIOMA NA FETUS}

Podaci o uticaju mioma na nastanak intrauterinog zastoja u rastu ploda su oprečni. Najčešći uzrok morbiditeta novorođenčadi majki sa miomima je prematuritet, s obzirom da se trudnoće žena sa miomima završavaju u mlađoj gestacionoj starosti [16].

Koronado i saradnici [25] su ukazali na povećan rizik od nižih Apgar skorova i male telesne mase kod dece majki sa miomima. U svojoj studiji, Staut i saradnici [21] navode da je intrauterina smrt ploda dva puta češća u trudnoćama komplikovanim miomima.

Lai i saradnici [16] su pokazali veću učestalost prevremenih porođaja kod trudnica sa miomima u odnosu na one bez mioma, u svim gestacionim starostima (kako pre 37. nedelje gestacije, tako i pre 34., 32. i 28. nedelje gestacije).

\section{TRETMAN MIOMA U TRUDNOĆI I TOKOM POROĐAJA}

Terapija mioma u trudnoći svodi se na mirovanje i praćenje trudnice uz simptomatsku terapiju u slučaju pojave bolova, kao i intenzivan nadzor stanja fetusa $[6,11]$.

Tretman bolova uzrokovanih crvenom degeneracijom mioma je konzervativan i podrazumeva primenu analgetika, rehidrataciju i odmor u postelji [11].

$\mathrm{U}$ slučaju prolapsa mioma u vaginu ne savetuje se miomektomija, jer ona može dovesti do nekontrolisanog krvarenja, rupture plodovih ovojaka i pobačaja, odnosno prevremenog porođaja. Pojava obilnog krvarenja, jakih bolova, retencije urina i infekcije predstavljaju indikacije za vaginalnu resekciju prolabiranih mioma u trudnoći [26].

Odluka o miomektomiji tokom trudnoće donosi se na osnovu gestacione starosti trudnoće, neuspeha u konzervativnom lečenju, anatomije mioma i postojanja degenerativnih i/ili inflamatornih promena [27]. Takođe treba uzeti u obzir i starosnu dob pacijentkinje i reproduktivnu anamnezu [6]. Rezultati su povoljniji ukoliko se miomektomija izvede u prvom i drugom trimestru trudnoće, naročito u slučaju mioma koji nisu u kontaktu sa materičnom šupljinom. Komplikacije do kojih može dovesti miomektomija u trudnoći su ne- nancy and delivery is uterine rupture. It can lead to bleeding, shock, hysterectomy, and even death of the mother and fetus [24]. It mostly occurs during the third trimester of pregnancy or during delivery, when intrauterine pressure is increased. Uterine scars, from previous myectomy, cause the decrease in the elasticity and firmness of the myometrium at the scar site, due to the replacement of muscular tissue by fibrous tissue. As a rule, in such cases, delivery usually ends in cesarean section $[11,24]$.

\section{THE EFFECT OF MYOMAS ON THE FETUS}

Data on the influence of myomas on the occurrence of intrauterine growth restriction are contradictory. The most common cause of infant morbidity in mothers with fibroids is premature birth, since pregnancies in women with myomas conclude at an earlier gestational age [16].

Coronado et al. [25] have indicated an increased risk of a lower Apgar score and of small body mass in children born to mothers with myomas. In their study, Stout et al. [21] state that intrauterine fetal death is twice more frequent in pregnancies complicated by myomas.

Lai et al. [16] have demonstrated a higher rate of premature deliveries in women with myomas, as compared to those without myomas, at all gestational ages (not only before the $37^{\text {th }}$ week of gestation, but also before the $34^{\text {th }}$ week, before the $32^{\text {nd }}$ week, and before the $28^{\text {th }}$ week of gestation).

\section{TREATMENT OF MYOMAS IN PREGNANCY AND DURING DELIVERY}

Treatment of myomas in pregnancy includes bed rest and follow-up with symptomatic therapy in case of pain, as well as intensive monitoring of the fetus $[6,11]$.

Treatment of pain caused by red degeneration of myomas is conservative and includes analgesics, rehydration, and bed rest [11].

In case of the prolapse of myomas into the vagina, myomectomy is not advised, as it can lead to uncontrolled hemorrhage, rupture of fetal membranes, and miscarriage, i.e., premature delivery. Heavy bleeding, intense pain, urine retention, and infection are indications for vaginal resection of the prolapsed myomas during pregnancy [26].

The decision on myectomy during pregnancy is made on the basis of the gestational age of the pregnancy, failure of conservative treatment, the anatomy of the myoma(s), and the existence of degenerative and/or inflammatory changes [27]. The age and the reproductive anamnesis of the patient should also be taken into account [6]. Results are more favorable if myectomy is carried out in the first or second trimester of the pregnancy, especially in the case of myomas 
kontrolisano krvarenje, transfuzija krvi, histerektomija i formiranje postoperativnih adhezija sa posledičnim sekundarnim infertilitetom [27].

Miomi se ne smatraju kontraindikacijom za vaginalni porođaj, čak ni u slučaju postojanja velikih mioma (promera većeg od $50 \mathrm{~mm}$ ) [11,26]. U slučajevima vaginalnog porođaja oni mogu da budu uzrok masivne postpartalne hemoragije, zbog smanjene kontraktilnosti materice, nekoordinisanih kontrakcija materice i mogućeg zaostajanja fragmenata posteljice. U nekim slučajevima se takva situacija može rešiti abdominalnom miomektomijom, uz očuvanje materice [28].

Miomektomija tokom carskog reza se godinama smatrala intervencijom koja može biti udružena sa visokim rizikom za razvoj intraoperativnih i neposrednih postoperativnih komplikacija [6]. U novije vreme sve je više studija koje pokazuju da miomektomija tokom carskog reza ne mora biti udružena sa povećanim rizikom pojave perioperativnih komplikacija [29].

Miomektomija tokom carskog reza omogućava izvođenje dve operacije u okviru jedne, pri čemu se izbegavaju rizici ponovne laparotomije i anestezije. Značajni faktori u donošenju odluke o ovom zahvatu su pored anatomske lokalizacije, broja i veličine mioma, i hirurško iskustvo akušera i postojanje sekundarne degeneracije mioma (Slika 2). Moguće je bezbedno odstraniti miome na peteljci i subserozne miome, dok se enukleacija intramuralnih i multiplih mioma tokom carskog reza ne preporučuje. Apsolutna kontraindikacija za miomektomiju tokom carskog reza je hipotonija i/ili atonija materice [29].

\section{KOMPLIKACIJE MIOMA U PUERPERIJUMU}

Postpartalne infekcije su češće kod žena sa miomima materice. Smatra se da miomi mogu biti uzrok rezidue placente posle porođaja i puerperalne sepse [6]. Pro-

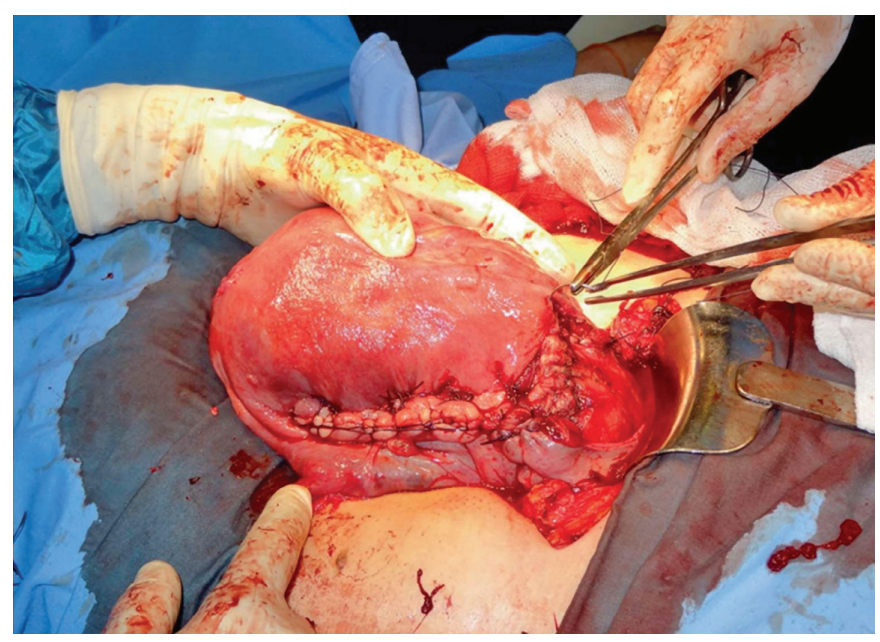

Slika 2. Materica nakon miomektomije tokom carskog reza

Figure 2. Uterus after myomectomy during cesarean section which are not in contact with the uterine cavity. The complications that myectomy can lead to in pregnancy are uncontrolled bleeding, blood transfusion, hysterectomy, and the formation of postoperative adhesions with consequent secondary infertility [27].

Fibroids are not considered a contraindication for vaginal delivery, even in the case of large myomas (diameter greater than $50 \mathrm{~mm}$ ) $[11,26]$. In cases of vaginal delivery, they can be the cause of massive postpartum hemorrhage, due to a reduced contractility of the uterus, uncoordinated contractions of the uterus, and possible retention of placental fragments. In some cases, such a situation may be resolved with abdominal myectomy, with the preservation of the uterus [28].

For years, myomectomy during cesarian section was considered to be a procedure which could be linked to a high risk of the development of intraoperative and immediate postoperative complications [6]. Lately, more and more studies have shown that myomectomy during cesarian section does not have to be linked to a higher risk of perioperative complications [29].

Myomectomy during cesarean section enables the performing of two operations within one surgical procedure, while avoiding the risks of repeated laparotomy and anesthesia. Significant factors in reaching a decision on this procedure are, in addition to anatomical localization and the number and size of the myomas, also the surgical experience of the obstetrician and the existence of secondary degeneration of the myomas (Figure 2). It is possible to safely remove pedunculated myomas and subserous myomas, whereas enucleation of intramural and multiple myomas during cesarean section is not recommended. An absolute contraindication for myomectomy during cesarean section is uterine hypotonia and/or uterine atony [29].

\section{MYOMA COMPLICATIONS IN THE PUERPERIUM}

Postpartum infections are more common in women with uterine myoma. It is believed that myomas may be the cause of placental residue after delivery or puerperal sepsis [6]. Prolonged febrile state in the postpartum period in patients with myomas may sometimes be caused by necrotic submucosal myoma contamination. Rarely, spontaneous expulsion of myomas into the vagina may occur during the puerperium [16].

The development of pyomyomas is a rare complication and it usually occurs after delivery or miscarriage, due to myoma infarction or infection. The predisposing factors for the development of pyomyomas include gynecological operations, vascular insufficiency, and immunodeficiency. Infection usually spreads per 
duženo febrilno stanje u postpartalnom periodu kod pacijentkinja sa miomima nekada može da bude prouzrokovano kontaminacijom nekrotičnih submukoznih mioma. Retko, u puerperijumu može doći do spontane ekspulzije mioma u vaginu [16].

Pojava piomioma je retka komplikacija i nastaje obično posle porođaja ili pobačaja usled infarkcije ili infekcije mioma. Predisponirajući faktori za njegov nastanak obuhvataju ginekološke operacije, vaskularnu insuficijenciju i imunodeficijenciju. Infekcija se obično širi per continuitatem iz materične šupljine, ali može nastati i hematogenim i limfogenim putem. Piomiomi se manifestuju visokom temperaturom, mada se u nekim slučajevima može javiti i jak bol u abdomenu. Leče se hirurški uz primenu antibiotika širokog spektra [30].

\section{ZAKLJUČAK}

Imajući u vidu tehnološki napredak u rezoluciji ultrazvučnih aparata, kao i trend odlaganja rađanja, može se očekivati povećanje prevalencije mioma u trudnoći. Ovo predstavlja značajan izazov za ginekologe i akušere u kontekstu unapređenja reproduktivnog zdravlja žena i sprečavanja eventualnog nastanka komplikacija koje miomi mogu izazvati u trudnoći, tokom porođaja i u puerperijumu.

Sukob interesa: Nije prijavljen.

\section{LITERATURA / REFERENCES}

1. Sparic R, Mirkovic L, Malvasi A, Tinelli A. Epidemiology of Uterine Myomas: A Review. Int J Fertil Steril. 2016 Jan-Mar; 9(4):424-35.

2. Donnez J, Dolmans MM. Uterine fibroid management: from the present to the future. Hum Reprod Update. 2016 Nov; 22(6):665-86.

3. Tinelli A, Sparic R, Kadija S, Babovic I, Tinelli R, Mynbaev OA, et al. Myomas: anatomy and related issues. Minerva Ginecol. 2016 Jun; 68(3):261-73.

4. Jayes FL, Liu B, Feng L, Aviles-Espinoza N, Leikin S, Leppert PC. Evidence of biomechanical and collagen heterogeneity in uterine fibroids. PLOS One. 2019 Apr 29; 14(4):e0215646.

5. Cardozo ER, Clark AD, Banks NK, Henne MB, Stegmann BJ, Segars JH. The estimated annual cost of uterine leiomyomata in the United States. Am J Obstet Gynecol. 2012 Mar; 206(3):211.e1-9.

6. Sparić R. Uterine myomas in pregnancy, childbirth and puerperium. Srp Arh Celok Lek. 2014 Jan-Feb; 142(1-2):118-24.

7. Klatsky PC, Tran ND, Caughey AB, Fujimoto VY. Fibroids and reproductive outcomes: a systematic literature review from conception to delivery. Am J Obstet Gynecol. 2008 Apr; 198(4):357-66.

8. Rubisz P, Ciebiera M, Hirnle L, Zgliczyńska M, Łoziński T, Dzięgiel P, et al. The Usefulness of Immunohistochemistry in the Differential Diagnosis of Lesions Originating from the Myometrium. Int J Mol Sci. 2019 Mar 6; 20(5):1136.

9. Stewart EA, Laughlin-Tommaso SK, Catherino WH, Lalitkumar S, Gupta D, Vollenhoven B. Uterine fibroids. Nat Rev Dis Primers. 2016 Jun 23; 2:16043.

10. Rosati P, Exacoustòs C, Mancuso S. Longitudinal evaluation of uterine myoma growth during pregnancy. A sonographic study. J Ultrasound Med. 1992 0ct; 11(10):511-5. continuitatem from the uterine cavity but may also develop via the hematogenous route and the lymphogenous route. Pyomyomas manifest with high body temperature, although in some cases, strong abdominal pain may occur. They are treated surgically with the application of broad spectrum antibiotics [30].

\section{CONCLUSION}

Bearing in mind the technological development in ultrasound machine resolution, as well as the trend of delaying childbearing, an increase in the prevalence of myomas in pregnancy can be expected. This represents a significant challenge for gynecologists and obstetricians in the context of promoting female reproductive health and preventing possible development of complications that myomas may cause in pregnancy, during delivery, and in the puerperium.

Conflict of interest: None declared.

11. Lee HJ, Norwitz ER, Shaw J. Contemporary management of fibroids in pregnancy. Rev Obstet Gynecol. 2010 Winter; 3(1):20-7.

12. Vitagliano A, Noventa M, Di Spiezio Sardo A, Saccone G, Gizzo S, Borgato S, et al. Uterine fibroid size modifications during pregnancy and puerperium: evidence from the first systematic review of literature. Arch Gynecol Obstet. $2018 \mathrm{Apr} ; 297(4): 823-35$.

13. Laughlin SK, Herring AH, Savitz DA, Olshan AF, Fielding JR, Hartmann KE, et al. Pregnancy-related fibroid reduction. Fertil Steril. 2010 Nov; 94(6):2421-3.

14. Delli Carpini G, Morini S, Papiccio M, Serri M, Damiani V, Grelloni C, et al. The association between childbirth, breastfeeding, and uterine fibroids: an observational study. Sci Rep. 2019 Jul 12; 9(1):10117.

15. Saleh HS, Mowafy HE, Hameid AAAE, Sherif HE, Mahfouz EM. Does Uterine Fibroid Adversely Affect Obstetric Outcome of Pregnancy? Biomed Res Int. 2018 Mar 26; 2018:8367068.

16. Lai J, Caughey AB, Qidwai GI, Jacoby AF. Neonatal outcomes in women with sonographically identified uterine leiomyomata. J Matern Fetal Neonatal Med. 2012 Jun; 25(6):710-3.

17. Swarray-Deen A, Mensah-Brown SA, Coleman J. Rare complication of fibroids in pregnancy: Spontaneous fibroid rupture. J Obstet Gynaecol Res. 2017 Sep; 43(9):1485-8.

18. Parazzini F, Tozzi L, Bianchi S. Pregnancy outcome and uterine fibroids. Best Pract Res Clin Obstet Gynaecol. 2016 Jul; 34:74-84.

19. Ouyang DW, Economy KE, Norwitz ER. Obstetric complications of fibroids. Obstet Gynecol Clin North Am. 2006 Mar; 33(1):153-69.

20. Jenabi E, Fereidooni B. The uterine leiomyoma and placenta previa: a meta-analysis. J Matern Fetal Neonatal Med. 2019 Apr; 32(7):1200-4. 
21. Stout MJ, Odibo A0, Graseck AS, Macones GA, Crane JP, Cahill AG. Leiomyomas at routine second-trimester ultrasound examination and adverse obstetric outcomes. Obstet Gynecol. 2010 Nov; 116(5):1056-63.

22. Michels KA, Velez Edwards DR, Baird DD, Savitz DA, Hartmann KE. Uterine leiomyomata and cesarean birth risk: a prospective cohort with standardized imaging. Ann Epidemiol. 2014 Feb; 24(2):122-6.

23. Milazzo GN, Catalano A, Badia V, Mallozzi M, Caserta D. Myoma and myomectomy: Poor evidence concern in pregnancy. J Obstet Gynaecol Res. 2017 Dec; 43(12):1789-804.

24. Frishman GN, Jurema MW. Myomas and myomectomy. J Minim Invasive Gynecol. 2005 Sep-0ct; 12(5):443-56.

25. Coronado GD, Marshall LM, Schwartz SM. Complications in pregnancy, labor, and delivery with uterine leiomyomas: A population-based study. Obstet Gynecol. 2000 May; 95(5):764-9.
26. Ezzedine D, Norwitz ER. Are Women With Uterine Fibroids at Increased Risk for Adverse Pregnancy Outcome? Clin Obstet Gynecol. 2016 Mar; 59(1):119-27.

27. Burton CA, Grimes DA, March CM. Surgical management of leiomyomata during pregnancy. Obstet Gynecol. 1989 Nov; 74(5):707-9.

28. Tower AM, Cronin B. Myomectomy after a vaginal delivery to treat postpartum hemorrhage resulting from an intracavitary leiomyoma. Obstet Gynecol. 2015 May; 125(5):1110-13.

29. Sparić R, Kadija S, Stefanović A, Spremović Radjenović S, Likić Ladjević I, Popović J, et al. Cesarean myomectomy in modern obstetrics: More light and fewer shadows. J Obstet Gynaecol Res. 2017 May; 43(5):798-804.

30. Magro M, Gafson I. Postpartum pyomyoma: A rare complication of leiomyoma. J Obstet Gynaecol. 2014 Feb; 34(2):202-3. 